\title{
Update of the erosive rain factor in Slovakia using data from the period 1961-2009
}

Milan ONDERKA ${ }^{1, *}$, Jozef PECHO ${ }^{1,2}$

${ }^{1}$ Comenius University, Faculty of Mathematics, Physics and Informatics, Department of Astronomy, Physics of the Earth and Meteorology, Mlynská dolina, Bratislava, Slovak Republic SK-82301

${ }^{2}$ Slovak Hydrometeorological Institute, Jeséniova 12, Bratislava, Slovak Republic SK-831 01

\begin{abstract}
An update of the rainfall erosivity factor (R-factor) estimated for 95 locations throughout the entire territory of Slovakia is presented in this paper. We analyzed rainfall time series with 1-minute resolution provided by the Slovak Hydrometeorological Institute. The data cover the period 1961-2009. The rain gauges are located at altitudes ranging from $97 \mathrm{~m}$ a.s.l. up to $1322 \mathrm{~m}$ a.s.l. and cover the broadest possible range of geographic regions and climatic conditions in Slovakia with reliable rainfall measurements. First, rainfall episodes were isolated by applying the fundamental rule that two subsequent rains are separated by at least six hours of no rainfall. A total of 116,710 rainfall events were identified and analyzed. A rainfall event was classified as erosive if the two following criteria were satisfied: the maximum 15-minute intensity $6.25 \mathrm{~mm}$ (i.e. $25 \mathrm{~mm} \mathrm{hr}^{-1}$, as originally used in the U.S.L.E. model, and/or rainfall depth was greater than $12.5 \mathrm{~mm}$. The presented estimates of R-factor are based on 18,467 identified erosive rainfall events. Furthermore, the minimum length of rainfall record necessary for reliable estimates of Rfactor has been estimated by spectral analysis. The Lomb-Scargle periodogram identified periodic behavior of the total kinetic rainfall energy and rainfall 15-minute intensities. We suggest that these periodicities are attributable mainly to the 11-year Sun spot cycle, the 18.6-year Luni-Solar cycle, and their higher harmonics. The spectral analysis also revealed that in order to capture the temporal variability the minimum length of timeseries in calculating $\mathrm{R}$-factors is $14-15$ years. We estimate that the long-term mean annual R-factor in Slovakia ranges from 34.8 $\mathrm{MJ} \mathrm{ha}^{-1} \mathrm{~cm} \mathrm{hr}^{-1}$ (at Gabčíkovo station) to $138 \mathrm{MJ} \mathrm{ha}^{-1} \mathrm{~cm} \mathrm{hr}^{-1}$ (at Tatranská Javorina station). The median value of the mean annual R-factors for the whole country is $71.13 \mathrm{MJ} \mathrm{ha}^{-1} \mathrm{~cm} \mathrm{hr}^{-1}$. To our best knowledge, the erosive rain factor has not been updated in Slovakia since the earlier work of Mišík in 1990. This paper is thus an update of the R-factors in Slovakia.
\end{abstract}

Key words: R-factor, erosive rain, USLE

*corresponding author: e-mail: milan.onderka@posteo.net 


\section{Introduction}

Soil erosion is considered as one of the major factors disrupting the ability of soil to provide plants with nutrients (Maderková et al., 2014; Jones et al., 2012; Panagos et al., 2017). In Europe, the most widespread form of soil degradation is caused by water erosion. It is estimated that some 105 million hectares, which corresponds to $16 \%$ of total Europe's arable land area, are affected by water erosion (Jones et al., 2012). According to the recent estimates of soil erosion in the investigated region (Kročková, 2010), some $39.65 \%$ (957 173 hectares) are affected by water erosion.

Given the adverse effects of soil loss in agriculture, soil erosion has also other implications for river morphology, siltation of water reservoirs and transport of sediment-bound contaminants (Onderka et al., 2012). In central Europe, soil erosion is caused mostly by heavy rainfall episodes. Shortterm heavy rains are much more damaging than long-lived and less dramatic rains (Routschek et al., 2014; Onderka, et al., 2012; Maderková et al., 2014). Routschek et al. (2014) investigated a process-based soil erosion model focusing on changes in erosion rates at high temporal and spatial resolution in three catchments in Germany under simulations of regional climate change using the A1B IPCC-scenario. The outputs from the soil erosion model revealed that, in Germany, the total number of rainstorms is expected to decrease in future while rainfall intensities are likely to increase. Routschek et al. (2014) further state that by the year 2050 the number of heavy rainstorms may decrease while rain intensities should increase, and that heavy rainstorms will mostly likely shift from summer to autumn and spring. Updating the $\mathrm{R}$ factor is therefore important also in terms of possible effects of climate change on rainfall intensity, volume and incidence.

Wischmeier and Smith (1978) suggested that at least 22 years of record are necessary for reliable estimates of $\mathrm{R}$ factors in North America. Malíšek (1990) suggested to analyze rainfall time series with a length of at least 15 years, however no explanation supporting this requirement was given. As the rainfall data used in this paper were collected in Slovakia with different climate, the cut-off length of record (22-years) needs to be verified for the local conditions.

As Prokoph et al. (2012) reported, the influence of solar irradiance and galactic cosmic ray flux on the precipitation variability has been long considered negligible because of the low power output of the Sun $(\sim 0.1 \%$ on 
decadal time scales) which can account for a global average temperature change within $0.1 \mathrm{~K}\left(E d d y, 19^{7} 6\right)$. Sunspot numbers are associated with a change in climate, including severe climatic conditions during the Maunder Minimum characterized by a lack of sunspots that occurred between the years 1640-1705. Terrestrial observations confirm that total solar irradiance increases with the number of sunspots, however, the total solar irradiance is higher at solar maximum even though sunspots are darker (cooler) than the average photosphere. White and Liu (2008) explained why the 11-year solar cycle may be viewed as a trigger for El Niño and La Niña events. Svensmark and Friis-Christensen (1997) explained that the fluctuation in the cosmic ray flux can be directly related to increases of aerosols and ion-charged raindrops. These mechanisms may be held responsible for the increase in cloud cover and potentially higher precipitation during periods of increased cosmic flux. Marsh and Svensmark (2000) found that global cloud cover is negatively correlated with the solar irradiance flux over 11 year sunspot cycles. Gachari et al. (2014) claims that the temporal distribution of sunspot numbers indicates that each turning point corresponds to events of severe hydrology in Kenya with a time lag of $5 \pm 2$ years. Therefore, such events hydrological events can be projected from sunspot forecasts. However, the prediction of sunspots is not an easy task and the current prediction of Cycle 24 appears to be at the end of the Modern Maximum (Gachari et al., 2014). Prokoph et al. (2012) showed that the 11 year sunspot cycles vary over time (averaging at 10.5 years). Moreover, Sunspot numbers exhibited large variations in their magnitude throughout the second half of the 20th century (Friis-Christensen and Lassen, 1991). Also, variability in solar activity such as the 11-year band is not translated linearly into climate functioning but likely through a series of non-linear oceanic-atmospheric responses, such as solar-intensity influence pressure anomaly perturbations and changing wind regimes (e.g. Hameed and Lee, 2005). Nuzhdina (2002) states that the 11year and 22-year cycles of solar activity are reflected in the dynamics of many meteorological processes such as atmospheric temperature, pressure and precipitation and that the precipitation in many regions of the Earth correlates with the 22-year cycle better than with the 11-year one. Prokoph et al. (2012) investigated the temporal regional influence of 11-year solar radiation periodicities on the maximum annual streamflow in Canada. They found that major runoff extremes are more likely to occur during sunspot 
cycles with relatively low sunspot numbers after the last maximum. Nuzhdina (2002) found that the 5.3-year oscillation, or the first subharmonic of the 11-year solar cycle is coherent in ENSO and Wolf number data.

To our best knowledge, erosive rain factors have not been updated in Slovakia since the earlier work of Malíšek (1990) who processed data from 86 stations. These point-estimates are still used in soil management on the national level using various methods of interpolation (Šruri et al., 2002). However, updating Mališek's estimates of erosive factor in Slovakia requires working with longer rainfall datasets and possibly a denser network of rain gauges (ك̌́ri et al., 2002).

We primary goals of this paper ore twofold: (1) to determine the minimum length of rainfall time-series for reliable estimates of R-factors in Slovakia; (2) to update R-factors for the entire territory of Slovakia.

\section{Materials and methods}

\subsection{Climate conditions}

The Slovak portion of the Carpathian range exhibits substantial spatial differences in climate. The local climate variability is attributable mainly to rather complex orographic conditions and air circulation patterns. The maritime influence on the local climate is controlled by the Atlantic and Mediterranean Sea. The maritime influence generally decreases from the West towards the East. Cyclones brought by the warm Mediterranean air are responsible for abundant rainfall, particularly in the southwestern and southern parts of the Slovak portion of the Carpathian range. On the other hand, the northwestern and northern parts are affected by cyclones of the Atlantic origin affect (Melo et al., 2013). Climatic regions and sub-regions of Slovakia are cold boreal forest climates according to the Köppen's climate classification (Melo et al., 2013).

The average yearly rainfall varies from about $520 \mathrm{~mm}$ up to $2000 \mathrm{~mm}$ in the High Tatras. Rainfall generally increases with altitude at the rate of about $50-60 \mathrm{~mm}$ for every 100 meters. About $40 \%$ of the yearly rainfall is observed in summer (June to August); while some $25 \%$ in spring; $20 \%$ in autumn. The remaining $15 \%$ of precipitation falls in winter. The Danube lowlands are among the driest areas of the investigated region with annual precipitation totals of $550 \mathrm{~mm}$. 


\subsection{Sources of data and Data quality}

The rainfall data used in this paper were taken from the national meteorological and climatological databases administered by the Slovak Hydrometeorological Institute. The network of rain gauges consists of 95 stations distributed homogeneously over the investigated area (Table 1). Our input rainfall data cover the "warm" period of the year when precipitation falls in the form as rain (April-October), hence the dormant season (NovemberMarch) was not analyzed. Nevertheless, the rain erosion index itself does not account for the erosive forces of thaw and snowmelt anyway (Wischmeier and Smith, 1978). The recent effort of the Slovak Hydrometeorological Institute to digitalize older rainfall records, and the subsequent extension of the database, makes it now possible to work with high-resolution data (1min) from additional stations. The elevations of the meteorological stations range from 97 meters a.s.l. to 1322 meters a.s.l. The length of rainfall timeseries used in this study varies between the stations from 14 years up to 49

years (Table 1). Stations with data covering 15 years and less are from the period 1991-2009. Stations with longer time series are based on data from the period 1961-2009.

\subsection{Identification of erosive rain episodes}

It is known that not every rainfall episode has the potential to cause significant soil erosion - i.e. is not erosive. Several authors discuss the threshold above which a rainfall episode triggers soil erosions (Hrnčiarová, 2001; Janeček et al., 2012; Kozlovská and Toman, 2016). A threshold rainfall depth of $12.5 \mathrm{~mm}$ was originally introduced for the Universal Soil Loss Erosion model (U.S.L.E.) by Wischmeier and Smith (1978). In the Revised U.S.L.E. model, on the other hand, $12.7 \mathrm{~mm}$ of total rainfall volume is applied (Panagos et al., 2017). Local small-scale field studies conducted by Hrnčiarová (2001) suggest that already a $10 \mathrm{~mm}$ rainfall may lead to soil erosion. However, for comparative reasons with studies conducted elsewhere in the investigated region (e.g. Janeček et al., 2012; Kozlovská and Toman, 2016), and also due to the wide-spread acceptance of the $12.5 \mathrm{~mm}$ threshold, we stick to the $12.5 \mathrm{~mm}$ threshold in our calculations of R-factors. In terms of maximum intensity of rainfall, we calculate maximum 15-min intensity of $6.25 \mathrm{~mm}$ (i.e. $25 \mathrm{~mm} \mathrm{hr}^{-1}$ ), as originally used in the U.S.L.E. model. Erosive 
Table 1. List of locations with estimated mean annual R-factors.

\begin{tabular}{|c|c|c|c|c|c|c|c|c|}
\hline 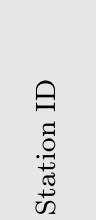 & Location & 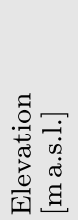 & 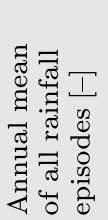 & 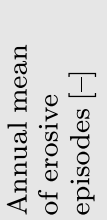 & 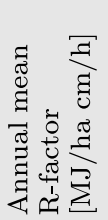 & 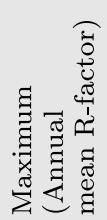 & 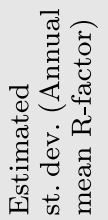 & 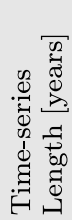 \\
\hline 11020 & Tatranská Javorina & 1017 & 75.0 & 19.0 & 138.3 & 319.4 & 76.7 & 15 \\
\hline 11120 & Cervený Kláštor & 469 & 68.5 & 13.0 & 95.0 & 188.2 & 46.8 & 15 \\
\hline 12040 & Poprad & 693 & 71.7 & 10.8 & 77.8 & 160.7 & 46.5 & 15 \\
\hline 12140 & Tatranská Lomnica & 825 & 53.9 & 8.9 & 60.8 & 192.3 & 45.2 & 15 \\
\hline 13100 & Podolínec & 569 & 70.8 & 11.9 & 79.9 & 129.0 & 29.8 & 15 \\
\hline 13220 & Plaveč nad Popradom & 485 & 71.6 & 11.9 & 108.0 & 274.7 & 63.6 & 14 \\
\hline 14050 & Holíč & 178 & 65.5 & 7.8 & 58.2 & 141.2 & 38.1 & 15 \\
\hline 15020 & Myjava & 348 & 68.3 & 9.1 & 64.3 & 198.0 & 42.4 & 20 \\
\hline 15140 & Senica & 228 & 61.7 & 8.4 & 67.2 & 159.8 & $\overline{52.3}$ & 20 \\
\hline 16140 & Kuchyña-Nový Dvor & 206 & 55.8 & 7.8 & 53.3 & 160.4 & 45.0 & 17 \\
\hline 17100 & $\begin{array}{l}\text { Bratislava- } \\
\text { Mudroňova ul. }\end{array}$ & 205 & 57.8 & 8.4 & 55.2 & 119.4 & 25.1 & 19 \\
\hline 17140 & Bratislava-Koliba & 283 & 70.1 & 9.6 & 68.0 & 201.5 & 42.0 & 15 \\
\hline 17300 & Komárno & 109 & 56.9 & 7.9 & 54.2 & 146.1 & 42.0 & 20 \\
\hline 17320 & Bratislava-letisko & 128 & 60.9 & 7.4 & 43.2 & 150.4 & 30.1 & 20 \\
\hline 17400 & Malý Javorník & 575 & 53.2 & 8.6 & 87.8 & 459.5 & $\overline{99.1}$ & 20 \\
\hline 17600 & Gabčíkovo & 114 & 47.3 & 5.7 & 34.8 & 117.6 & 24.3 & 42 \\
\hline 17680 & Žihárec & 111 & 62.7 & 7.9 & 63.0 & 153.3 & 42.7 & 15 \\
\hline 18040 & Králová pri Senci & 121 & 57.1 & 6.4 & 47.5 & 203.3 & 47.8 & 16 \\
\hline 18260 & Jaslovské Bohunice & 176 & 64.3 & 8.3 & 61.9 & 173.1 & 42.1 & 23 \\
\hline 18380 & Trnava & 146 & 58.8 & 7.4 & 60.9 & 328.3 & $\overline{71.2}$ & 18 \\
\hline 18560 & Sered' & 126 & 49.6 & 6.9 & 41.9 & 151.4 & 32.3 & 48 \\
\hline 19040 & Hurbanovo & 115 & 64.1 & 8.0 & 48.1 & 133.0 & 30.3 & 49 \\
\hline 20020 & Liptovská Teplička & 916 & 64.3 & 12.3 & 82.6 & 179.0 & 39.3 & 15 \\
\hline 20040 & $\begin{array}{l}\text { Král'ová Lehota- } \\
\text { Čierny Váh }\end{array}$ & 762 & 62.9 & 9.3 & 46.1 & 126.1 & 31.4 & 15 \\
\hline 20080 & Strbské Pleso & 1322 & 68.1 & 12.4 & 73.4 & 208.1 & 34.5 & 49 \\
\hline 20220 & Podbanské & 978 & 76.8 & 13.1 & 86.1 & 353.8 & 79.7 & 15 \\
\hline 20260 & Liptovský Hrádok & 640 & 60.6 & 9.0 & 48.8 & 105.1 & 27.4 & 43 \\
\hline 21130 & $\begin{array}{l}\text { Liptovský Mikuláš- } \\
\text { Ondrašová }\end{array}$ & 570 & 64.7 & 8.7 & 47.0 & 127.7 & 31.2 & 15 \\
\hline 21180 & Huty & 808 & 52.2 & 9.6 & 55.0 & 101.4 & 29.5 & 14 \\
\hline 21360 & Liptovská Osada & 605 & 63.2 & 11.6 & 79.4 & 138.8 & 35.1 & 14 \\
\hline 21460 & Lubochňa & 444 & 66.1 & 11.8 & 67.6 & 111.6 & 29.1 & 15 \\
\hline 22020 & Oravská Lesná & 785 & 68.5 & 13.9 & 75.5 & 184.4 & 32.2 & 42 \\
\hline 22130 & Oravské Veselé & 754 & 74.7 & 10.9 & 65.5 & 165.3 & 41.3 & 15 \\
\hline 23020 & $\begin{array}{l}\text { Trstená-Ústie } \\
\text { nad Priehradou }\end{array}$ & 604 & 67.3 & 10.1 & 57.2 & 128.8 & 32.1 & 14 \\
\hline 23060 & Vitanová - Oravice & 856 & 66.5 & 15.3 & 115.9 & 312.5 & 73.0 & 15 \\
\hline 23090 & Liesek & 690 & 85.5 & 14.4 & 90.2 & 148.2 & 29.8 & 15 \\
\hline 23180 & Oravský Biely Potok & 648 & 67.5 & 13.2 & 81.4 & 115.2 & 27.8 & 15 \\
\hline
\end{tabular}




\begin{tabular}{|c|c|c|c|c|c|c|c|c|}
\hline 25040 & Žilina & 365 & 72.9 & 12.1 & 64.2 & 137.5 & 33.0 & 15 \\
\hline 25120 & Čadca & 432 & 71.7 & 11.6 & 70.0 & 132.1 & 31.9 & 15 \\
\hline 25180 & Stará Bystrica & 478 & 71.1 & 14.2 & 114.3 & 212.6 & 56.6 & 15 \\
\hline 25240 & Kysucké Nové Mesto & 365 & 66.7 & 11.1 & 75.2 & 174.1 & 48.6 & 15 \\
\hline 25320 & Kunerád & 536 & 74.0 & 12.5 & 78.7 & 194.9 & 47.2 & 15 \\
\hline 26040 & Dolný Hričov & 309 & 72.4 & 11.2 & 59.2 & 116.5 & 24.6 & 20 \\
\hline 26060 & Vel'ké Rovné & 538 & 64.8 & 11.1 & 71.1 & 156.2 & 38.3 & 15 \\
\hline 27040 & Beluša & 253 & 74.1 & 11.7 & 68.7 & 134.2 & 31.7 & 15 \\
\hline 28100 & Trenčín & 295 & 62.8 & 9.5 & 69.2 & 166.1 & 40.5 & 17 \\
\hline 28200 & Pieštany & 161 & 67.9 & 9.4 & 60.3 & 129.3 & 25.7 & 16 \\
\hline 30120 & Prievidza & 256 & 71.6 & 9.7 & 65.6 & 191.6 & 40.9 & 20 \\
\hline 30200 & Valaská Belá & 463 & 69.0 & 11.9 & 86.8 & 179.2 & 47.6 & 15 \\
\hline 31040 & Topol'čany & 176 & 64.6 & 8.9 & 60.8 & 147.8 & 32.4 & 19 \\
\hline 31320 & Nitra - Velké Janíkovce & 132 & 61.4 & 8.3 & 47.4 & 152.6 & 34.5 & 19 \\
\hline 31400 & Nové Zámky & 111 & 55.0 & 6.9 & 46.0 & 162.7 & 33.4 & 48 \\
\hline 32200 & Mochovce & 260 & 61.5 & 9.2 & 57.8 & 115.4 & 30.5 & 20 \\
\hline 32280 & Podhájska & 145 & 62.3 & 8.5 & 51.4 & 99.4 & 33.1 & 16 \\
\hline 33020 & Telgárt & 900 & 69.8 & 15.3 & 93.0 & 176.6 & 39.3 & 15 \\
\hline 33200 & Brezno & 485 & 71.5 & 12.0 & 86.3 & 257.2 & 66.3 & 15 \\
\hline 34340 & Sliač & 310 & 61.9 & 8.8 & 64.0 & 144.2 & 36.1 & 43 \\
\hline 35140 & Vígl'aš Pstruša & 365 & 57.7 & 9.3 & 73.8 & 192.3 & 48.1 & 15 \\
\hline 36090 & Kremnické Bane & 763 & 76.0 & 11.7 & 79.3 & 196.6 & 44.9 & 15 \\
\hline 36180 & Žiar nad Hronom & 275 & 72.4 & 9.7 & 61.5 & 166.3 & 38.1 & 15 \\
\hline 38120 & Bol'kovce & 210 & 63.6 & 10.6 & 82.5 & 210.6 & 60.7 & 14 \\
\hline 39200 & Dolné Plachtince & 231 & 63.5 & 10.7 & 82.5 & 175.7 & 51.9 & 15 \\
\hline 40120 & Sahy & 145 & 51.0 & 8.3 & 60.6 & 173.0 & 50.9 & 20 \\
\hline 40160 & Bzovík & 351 & 59.9 & 9.3 & 70.7 & 159.0 & 41.6 & 15 \\
\hline 40260 & Banská Štiavnica & 562 & 68.9 & 11.4 & 66.6 & 166.8 & 46.7 & 15 \\
\hline 40320 & Ladzany & 212 & 66.6 & 9.9 & 84.5 & 200.6 & 55.4 & 14 \\
\hline 40380 & Dudince & 137 & 62.7 & 10.0 & 80.4 & 186.4 & 52.2 & 15 \\
\hline 43060 & Medzilaborce & 306 & 70.7 & 13.0 & 89.2 & 180.8 & 40.2 & 15 \\
\hline 43100 & Cabiny & 253 & 67.4 & 11.5 & 84.8 & 193.2 & 52.4 & 15 \\
\hline 43160 & Osadné & 380 & 64.9 & 11.3 & 75.1 & 177.2 & 49.7 & 15 \\
\hline 43220 & Papin & 267 & 65.3 & 12.5 & 87.4 & 173.7 & 41.3 & 15 \\
\hline 43360 & Snina & 211 & 49.7 & 9.2 & 68.2 & 193.5 & 51.5 & 14 \\
\hline 43400 & Kamenica nad Cirochou & 176 & 72.4 & 12.2 & 84.9 & 157.0 & 33.3 & 49 \\
\hline 44020 & Humenné & 145 & 62.7 & 10.8 & 67.3 & 138.1 & 33.7 & 14 \\
\hline 46200 & Michalovce & 110 & 76.7 & 10.6 & 79.0 & 160.8 & 40.0 & 15 \\
\hline 48120 & Tisinec & 208 & 78.0 & 12.9 & 88.0 & 173.2 & 40.8 & 15 \\
\hline 49120 & Bardejov & 312 & 58.6 & 8.9 & 50.1 & 116.7 & 25.9 & 15 \\
\hline 49380 & Caklov & 140 & 62.1 & 10.3 & 66.0 & 132.0 & 39.2 & 15 \\
\hline 50080 & Milhostov & 102 & 71.5 & 10.1 & 84.7 & 221.5 & 62.3 & 15 \\
\hline 51020 & Leles & 100 & 62.1 & 10.0 & 79.9 & 195.6 & 49.6 & 15 \\
\hline 51060 & Somotor & 97 & 60.8 & 8.1 & 43.1 & 127.3 & 32.0 & 15 \\
\hline 52140 & Rožňava & 311 & 70.7 & 11.7 & 123.2 & 380.9 & 89.2 & 15 \\
\hline 53220 & Ratková & 304 & 75.5 & 13.1 & 126.5 & 294.9 & 70.7 & 15 \\
\hline 54120 & Lom nad Rimavicou & 1018 & 60.6 & 11.9 & 91.4 & 205.2 & 51.5 & 14 \\
\hline 54200 & Rimavská Sobota & 209 & 66.5 & 9.1 & 64.7 & 127.1 & 34.4 & 14 \\
\hline 54380 & Ćíž & 164 & 65.3 & 9.1 & 67.4 & 161.4 & 46.3 & 15 \\
\hline
\end{tabular}




\begin{tabular}{|l|l|c|c|c|c|c|c|c|}
\hline 55020 & Stós-Kúpele & 599 & 70.1 & 12.9 & 104.8 & 171.5 & 40.1 & 15 \\
\hline 55080 & Moldava n. Bodvou & 206 & 69.7 & 10.2 & 74.3 & 158.2 & 36.5 & 15 \\
\hline 56120 & Spišská Nová Ves & 453 & 55.5 & 9.7 & 73.2 & 221.8 & 50.7 & 15 \\
\hline 56200 & Spišské Vlachy & 382 & 68.2 & 11.7 & 93.6 & 170.8 & 41.7 & 15 \\
\hline 57120 & Švedlár & 477 & 64.7 & 12.7 & 106.3 & 227.1 & 54.9 & 15 \\
\hline 57180 & Gelnica & 357 & 62.0 & 11.1 & 96.0 & 231.7 & 56.1 & 15 \\
\hline 58220 & Košice-Mesto & 207 & 73.0 & 10.7 & 74.1 & 175.7 & 44.4 & 15 \\
\hline 59120 & Jakubovany & 407 & 72.0 & 11.3 & 91.7 & 184.6 & 45.0 & 15 \\
\hline 60120 & Košice - letisko & 229 & 67.7 & 10.4 & 89.9 & 302.0 & 54.4 & 49 \\
\hline & max & 1322 & 85.5 & 19.0 & 138.3 & 459.5 & 99.1 & 49 \\
\hline & min & 97 & 47.3 & 5.7 & 34.8 & 99.4 & 24.3 & 14 \\
\hline & avrg & 389.1 & 65.6 & 10.5 & 73.7 & 180.3 & 43.8 & 19 \\
\hline
\end{tabular}

episodes were identified applying the following criteria: $12.5 \mathrm{~mm}$ threshold of total rainfall depth and/or $6.25 \mathrm{~mm}$ as maximum 15-min intensity. The separated potentially erosive rain episodes were not divided into segments of equal intensity, as originally proposed by Wischmeier and Smith (1978). Our approach was to consider each measurement interval as a unique rain segment of equal intensity. The database used in this paper consist of time series of rainfall data with 1-minute resolution, hence the length of the rainfall segments equals one minute.

\subsection{Calculation of R-factors}

For the calculation of the R-factor we used the metric version of the empirical equation developed originally by Wischmeier and Smith (1978) and used in its original or modified form i.e. in Mališek (1990); Šŕri et al. (2002); Janeček et al. (2012); Kozlovská and Toman (2016). The $R$ factor was computed from the rainfall measurements collected at 95 locations (Table 1) distributed throughout investigated area.

The erosive factor $R$ is defined as follows:

$R=\frac{1}{N} \sum_{1}^{N}\left(E_{t o t} I_{30}\right)$,

where $R$ [MJ ha ${ }^{-1} \mathrm{~cm} \mathrm{~h}^{-1}$ ] is the rain erosivity factor averaged for a period of length $N$. The rain erosivity factor is a product of total storm energy $E_{t o t}$ (Eq. 2) multiplied by the maximum 30-minute intensity $I_{30}$. The sum of the storm $E_{t o t} I_{30}$ values (energy-times-intensity parameter) for a given period is the numerical measure of the erosive potential of the rainfall within that 
period. According to Wischmeier and Smith (1978), soil losses are linearly proportional to the $E_{t o t} I_{30}$ parameter. The product $E_{t o t} I_{30}$ combines the effects of both the energy and intensity on the erosive potential:

$E_{t o t}=\sum_{i=1}^{n} E_{i}$,

where $E_{i}$ is kinetic energy of the $i$-th rainfall segment. The total kinetic energy of an erosive event is a sum of all rainfall segments $n$ (Eq. 3).

$E_{i}=\left(206+87 \log I_{S}\right) H_{S}$,

where $I_{S}\left[\mathrm{~mm} \mathrm{hr}^{-1}\right]$ and $H_{S}[\mathrm{~mm}]$ are the intensity and height of a rainfall segment, respectively.

To answer the question as to how long time series have to be for reliable estimates of erosive factor, we use spectral analysis to decipher the dominant periods in the rain signal. Since rainfall episodes occur isolated in time and are separated by no rain intervals, classical spectral techniques such as the Fast Fourier Transform cannot be used because the treated signal contains gaps. To overcome the problem of unevenly sampled data, we use the LombScargle periodogram described in Lomb (1976) and VanderPlas (2018).

\section{Results}

Fig. 1 shows how the mean annual occurances of all rain episodes including non-erosive rains are distributed throughout the country. No striking pattern in the geographical distribution of the annual rainfall frequency was observed. On the other hand, as Fig. 2 suggests the least erosive rains fall in the western portion of the country with 5-10 episodes per year. The highest incidence of erosive rains was found to dominate in the central, northern and eastern sections of the country. In terms of the magnitude of R-factors, the highest R-factors were calculated for the mountainous regions (Fig. 3), suggesting a positive correlation between $\mathrm{R}$-factor and altitude.

The summary statistics of erosive events on annual basis is listed in Table 1 . We estimate the long-term annual average $\mathrm{R}$-factor to range from $34.8 \mathrm{MJ} \mathrm{ha}^{-1} \mathrm{~cm} \mathrm{hr}^{-1}$ (at Gabčíkovo) to $138 \mathrm{MJ} \mathrm{ha}^{-1} \mathrm{~cm} \mathrm{hr}^{-1}$ (at Tatranská 


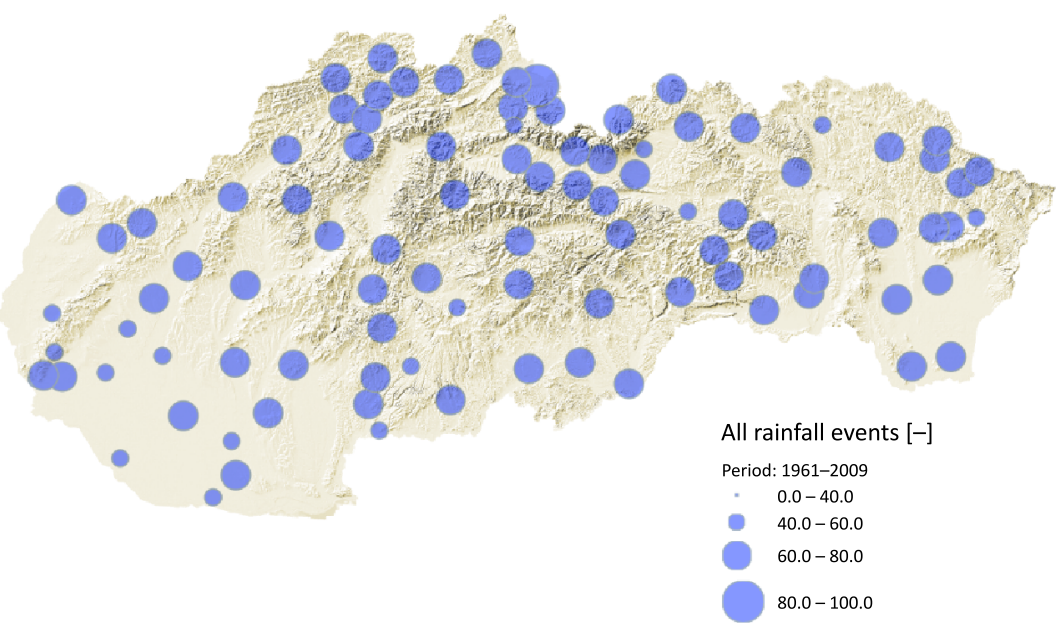

Fig. 1. Long-term mean annual incidence of all rain episodes (including non-erosive rains).

Javorina). As shown in Fig. 4, the point-estimates of the annual mean Rfactors are log-normally distributed. The median value of the annual mean $\mathrm{R}$-factors for the whole country is $71.13 \mathrm{MJ} \mathrm{ha}^{-1} \mathrm{~cm} \mathrm{hr}^{-1}$. The mean annual R-factors calculated for the 95 considered locations in Slovakia show a lognormal distribution (Fig. 4).

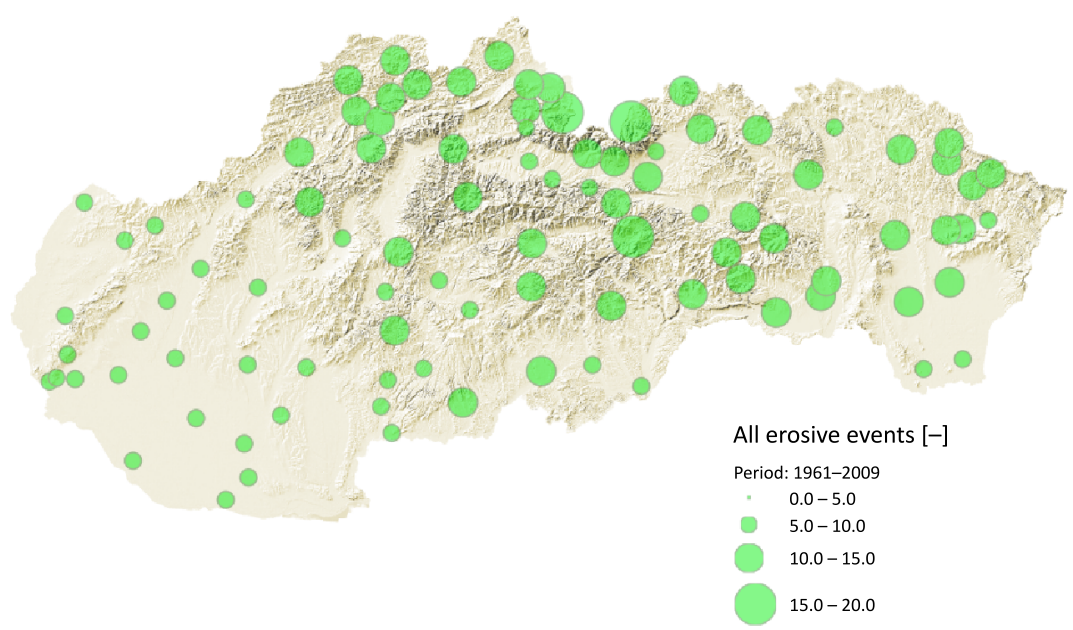

Fig. 2. Long-term mean annual incidence of erosive rain episodes (episodes fulfilling the conditions of 15-min intensity $6.25 \mathrm{~mm}$ and/or a total rainfall depth $>12.5 \mathrm{~mm}$ ). 


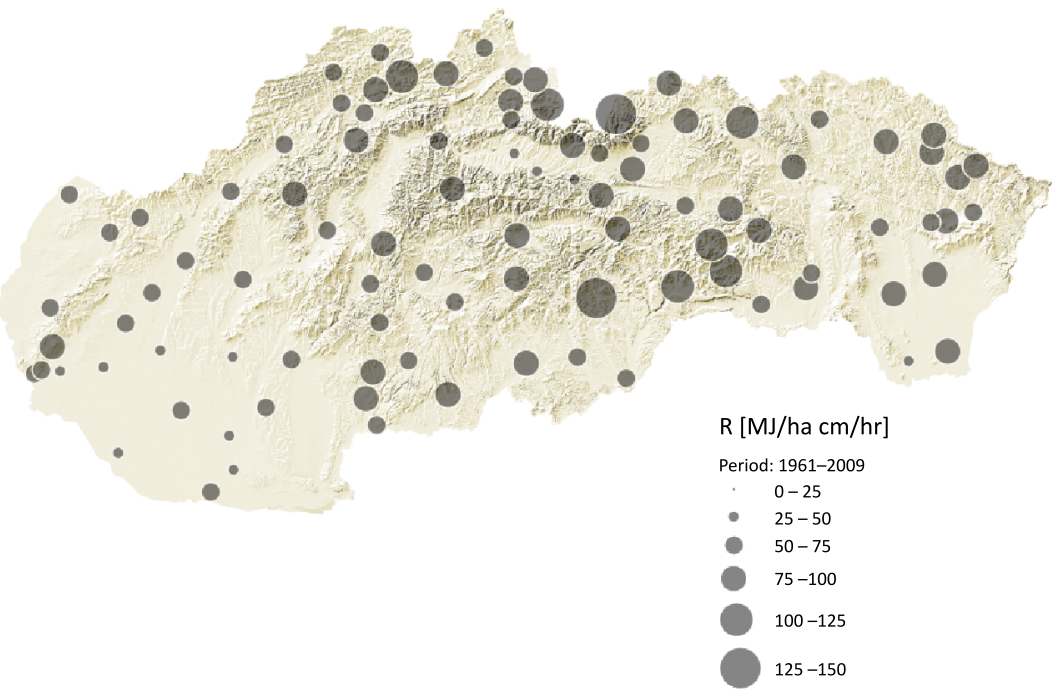

Fig. 3. Long-term mean annual R-factor.

With the Lomb-Scargle periodogram we identified and described six apparent periodicities located at 0.5 year, 1 years, 3-4 years, 7-9 years, 11 years, 22 years in total kinetic energy and maximum 30-minute intensities. This finding is important in terms of choosing the minimum length of

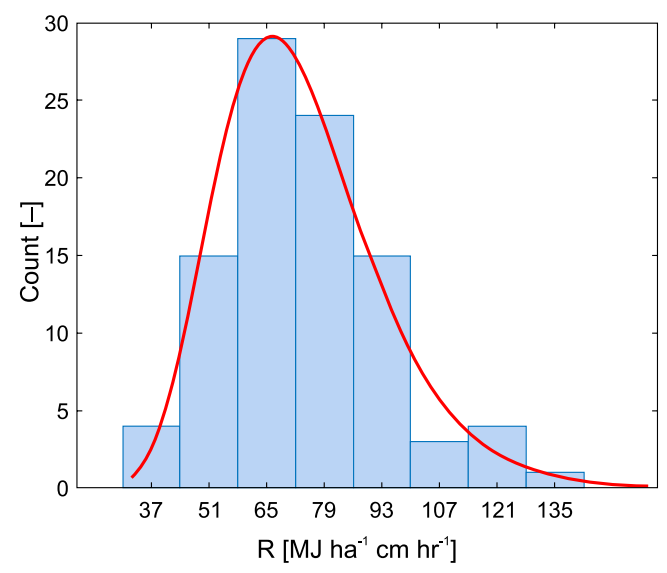

Fig. 4. Histogram of mean annual R-factors estimated for the individual locations listed in Table 1 . The R-factors are Log-normally distributed. The median value of the $\mathrm{R}$-factor is $71.13 \mathrm{MJ} \mathrm{ha}^{-1} \mathrm{~cm} \mathrm{hr}^{-1}$. 
record when analyzing $R$ factors and their temporal behavior. The individual periodicities (cycles) are labeled in Fig. 5 as letters "A" though "G". Periodicities of 0.5 and 1-year origin in the annual cycle of rainfall and its 0.5-year sub-harmonics (labeled as $\mathrm{A}-\mathrm{B}$ ). Periodicities in the range 3 to 4 years (label $\mathrm{C}$ ) are probably related to either $\mathrm{QBO}$ or the higher harmonics of the 11-year Sunspot cycle at 3.7 years. Periodicities located within the range 7 to 9 years (label D) are probably related to the 7.4 harmonic that result from the combination of the Sun's 11-year and 22-year cycles. Periodicities in the range 10.7 to 11.1 years (label E) originate in the Sun spot cycle. Periodicities in the range 17.9 to 19.6 (label F) are attributed to the 18.6-year Luni-Solar cycle. Periodicities in the range 32 to 34 years (label $\mathrm{G}$ ) have not been related to any physical phenomena, nevertheless, these periodicities are small compared to top other cycles in the presented spectra in Fig. 5a,c. The spectrogram of maximum 30-min intensities is shown in Fig. 5b, where only the annual and its half-year sub-harmonics are visi-

a)

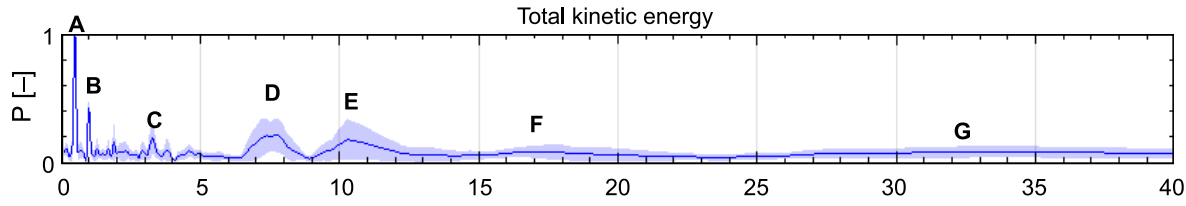

b)

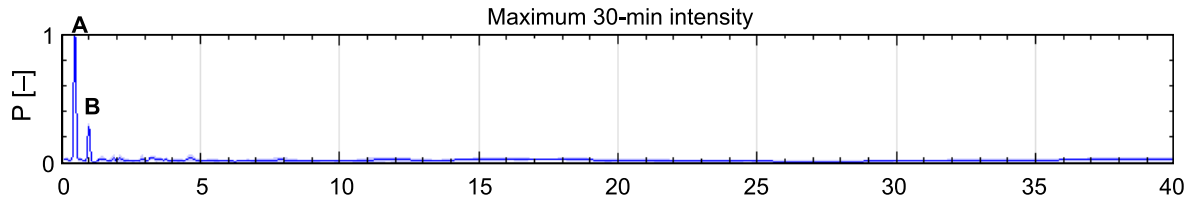

c)

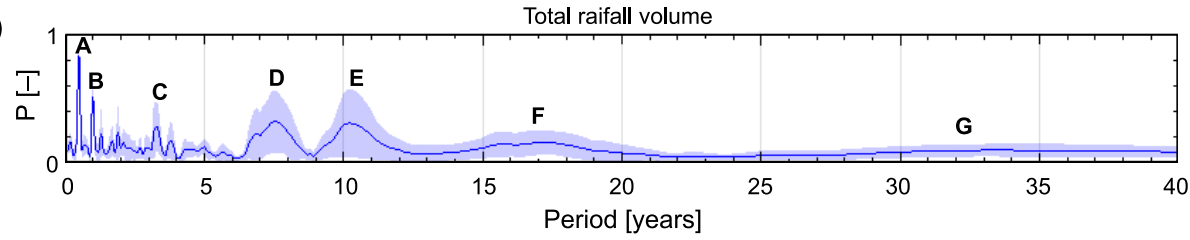

Fig. 5. Normalized power spectra of the Lomb-Scargle periodogram generated for: a) total kinetic energy (Eq. 2) of all registered rainfall episodes; b) maximum 30-minute intensities of all registered rainfall episodes; c) total rainfall volume of all registered rainfall episodes. The bluish areas indicate the spread (upper and lower quartiles) of the spectra generated form 10 station with the longest period of record ( $>40$ years). The solid lines indicate the medians of the processed spectra. The major cycles are indicted as letter A through $\mathrm{G}$ at the corresponding periods. The power spectra were normalized to range from 0 to 1 as $[\mathrm{P}-\min (\mathrm{P})] /[\max (\mathrm{P})-\min (\mathrm{P})]$, where $\mathrm{P}$ is the power. 
ble. The spectrograms show that the greatest amount of signal variability is located at periods below approximately $13-14$ years. This implies that the minimum length of rainfall time-series is approx. 14-15 years. Longer time-series would contain additional signal from the 18.6-year Luni-Solar cycle.

\section{Discussion}

Erosive rain factors have not been updated in Slovakia since the early 1990s when Malíšek (1990) processed data from 86 stations. Our primary objective was to update the estimates of R-factors using more recent data from additional stations. In addition, the results presented in this paper are derived from high resolution 1-minute rainfall data and are published for a total of 95 locations for the first time. Malíšek (1990) suggested to analyze rainfall time series with a length of at least 15 years, however no explanation supporting this requirement was given. Our spectral analyses confirm that at least 14 years of rainfall data are needed to capture the 11-year Solar cycle in rainfall data. As Gusev et al. (2004) state, the existence of decadal and bi-decadal periods in rainfall data is an evidence of solar activity's effect on the Earth's climate, and that examples of this correlation are short-lived events such as solar flares; up to the 11-year, the 22-year Hale cycle, and possibly even longer solar radiation changes. Further periodicities that have been identified in rainfall, as described in Ramachandra Rao et al. (2003), are located at 4 to 6 years and are attributable to 6-year ENSO cycles, which another 5.5 year sub-harmonic cycle of the Sun spots. Ramachandra Rao et al. (2003) described a 6.9-year periodicity and attributed this to the interaction of the 11-year sunspot cycle and the 18.6-year Lunar-Solar cycle. The spectra presented in our paper suggest that the 6.9-year cycle is very small and is detected only in the total rainfall volume series.

The summary statistics of erosive events on annual basis is listed in Table 1 . We estimate the long-term annual average R-factor to range from $34.8 \mathrm{MJ} \mathrm{ha}^{-1} \mathrm{~cm} \mathrm{hr}^{-1}$ (at Gabčíkovo) to $138 \mathrm{MJ} \mathrm{ha}^{-1} \mathrm{~cm} \mathrm{hr}^{-1}$ (at Tatranská Javorina). The median value of the annual mean $\mathrm{R}$-factors for the whole country is $71.13 \mathrm{MJ} \mathrm{ha}^{-1} \mathrm{~cm} \mathrm{hr}^{-1}$.

The Rainfall Erosivity Database at European Scale has been lately published providing maps of R-factors for Europe including the region inves- 
tigated in our project Ballabio et al. (2017). The R-factors calculated by Ballabio et al. (2017) seem to be within the range of R-factors presented in this paper. The range of annual R-factors calculated for the 95 locations (Table 1) is from 34.8 to $138.3 \mathrm{MJ} \mathrm{ha}^{-1} \mathrm{~cm} \mathrm{hr}^{-1}$ (Table 1). The R-factors calculated in this paper seem to be somewhat higher than the values published in the earlier work of Malíšek (1990) who calculated annual mean $\mathrm{R}$-factors within range of 5 and $30 \mathrm{MJ} \mathrm{ha}^{-1} \mathrm{~cm} \mathrm{hr}^{-1}$. One possible explanation of these differences might be the fact that Mališek (1990) selected erosive events manually, whereas we deployed an automatic selection procedure. Another explanation is that we used 1-min resolution data. Also Maderková et al. (2014) and Antal et al. (2015) calculated R-factors for selected sites near the city of Nitra, Slovakia with higher values than those presented in Malíšek (1990).

\section{Conclusions}

We have identified several dominant periodicities that are attributable to major climatic indices including the Solar activity affecting the long-term behavior of R-factor. This information has implications for reliable estimates of R-factors for stations with short rainfall measurements. We can conclude that the spectral analysis revealed that in order to capture the most of the temporal variability in rainfall signal, the minimum length of time-series for R-factor calculations is $14-15$ years. Longer time series might give more precise results as the 22-year Hale's cycle constitutes additional signal variability.

To our best knowledge, erosive rain factors have not been updated in Slovakia since the early 1990s. The results presented in this paper are derived from high resolution 1-minute rainfall data and are published for a total of 95 locations for the first time. For instance, Malíšek (1990) processed data from 86 stations. As such, our results have the potential to substantially improve the regional estimates of soil erosion rates in the investigated region and to adjust erosion control measures.

We have updated the estimates of annual R-factors in a climatically and geographically complex region of Slovakia for rainfall data covering the period 1961-2009. We estimated the long-term annual average R-factor to 
range from 34.8 $\mathrm{MJ} \mathrm{ha}^{-1} \mathrm{~cm} \mathrm{hr}^{-1}$ (at Gabčíkovo) to $138 \mathrm{MJ} \mathrm{ha}^{-1} \mathrm{~cm} \mathrm{hr}^{-1}$ (at Tatranská Javorina). The median value of the annual mean $\mathrm{R}$-factors for the whole country is $71.13 \mathrm{MJ} \mathrm{ha}^{-1} \mathrm{~cm} \mathrm{hr}^{-1}$.

Finally, we are convinced that the peer researchers and other soil erosion experts will find the updated point-estimates of R-factors in Slovakia interesting to improve soil erosion estimates. As our database cover the years 1961-2009, it would be interesting for the future research to further work on extending the length of time series and focus on potential effects of climate change on the erosive potential of rainfall.

Acknowledgements. This work was supported by the "Science and Research" Operational Program, Project: "Applied research of methods for determination of climatological and hydrological design quantities", ITMS: 26220220132, co-financed by the European Regional Development Fund.

\section{References}

Antal J., Maderková L., Eimo J., Drgoňová K., 2015: Analysis of calculation methods for determination of rain erosivity for Slovak Republic. Acta Sci. Pol. Formatio Circumiectus, 14, 4, 5-14.

Ballabio C., Borrelli P., Spinoni J., Meusburger K., Michaelides S., Beguería S., Klik A., Petan S., Janeček M., Olsen P., Aalto J., Lakatos M., Rymszewicz A., Dumitrescu A., Tadić M. P., Diodato N., Kostalova J., Rousseva S., Banasik K., Alewell C., Panagos P., 2017: Mapping monthly rainfall erosivity in Europe. Sci. Total Environ., 579, 1298-1315, doi: 10.1016/j.scitotenv.2016.11.123.

Eddy J. A., 1976: The Maunder Minimum. Science, New Series, 192, 1189-1202.

Friis-Christensen E., Lassen K., 1991: Length of the solar cycle: An indicator of solar activity closely associated with climate. Science, 254, 5032, 698-700, doi : 10.1126/ science.254.5032.698.

Gachari F., Mulati D. M., Mutuku J. N., 2014: Sunspot numbers: Implications on Eastern African rainfall. S. Afr. J. Sci., 110, 1-5, doi: 10.1590/sajs.2014/20130050.

Gusev A., Martin I., Mello M. G., Pankov V., Pugacheva G., Schuch N., Spjeldvik W., 2004: Bidecadal cycles in liquid precipitations in Brazil. Adv. Sp. Res., 34, 370-375, doi : 10.1016/j.asr.2003.03.048.

Hameed S., Lee J. N., 2005: A mechanism for sun-climate connection. Geophys. Res. Lett., 32, 1-3, doi : 10.1029/2005GL024393.

Hrnčiarová T., 2001: Ecological optimization of agricultural landscape (Dolná Malanta model area) (Ekologická optimalizácia polnohospodárskej krajiny (modelové územie Dolná Malanta)). VEDA, ISBN 80-224-0664-3, pp 134. (in Slovak). 
Janeček M., Květoň V., Kubátová E., Kobzová D., 2012: Differentiation and regionalization of rainfall erosivity factor values in the Czech Republic. Soil Water Res., 7, 1, 1-9, doi: 10.17221/2/2011-SWR.

Jones A., Panagos P., Barcelo S., Bouraoui F., Bosco C., Dewitte O., Gardi C., Erhard M., Hervás J., Hiederer R., Jeffery S., Lükewille A., Marmo L., Montanarella L., Olazábal C., Petersen J.-E., Penizek V., Strassburger T., Tóth G., Van Den Eeckhaut M., Van Liedekerke M., Verheijen F., Viestova E., Yigini Y., 2012: The State of Soil in Europe - a Contribution of the JRC to the European Environment Agency's Environment State and Outlook report SOER 2010. European Environment Agency, Institute for Environment and Sustainability, ISBN 978-9279-22806-3, doi: 10.2788/77361.

Kozlovská S., Toman F., 2016: Occurrence of erosion-effective rain in the Brno area. Acta Univ. Agric. Silvic. Mendelianae Brun., 64, 1583-1591, doi: 10.11118/actaun2016 64051583

Kročková B., 2010: Soil as an environmental component of the Slovak Republic in 2010 (Pôda ako zložka životného prostredia v Slovenskej republike k roku 2010). Banská Bystrica. Indication Report 2010. Slovenská agentúra životného prostredia Banská Bystrica (Slovak Environmental Protection Agency), pp 45, (in Slovak).

Lomb N. R., 1976: Least-squares frequency analysis of unequally spaced data. Astrophys. Space Sci., 39, 447-462, doi : 10.1007/BF00648343.

Maderková L., Antal J., Čimo J., 2014: Statistic and probability characteristics of rain factor R in Slovak Republic. Eurasian J. Soil Sci., 3, 4, 254-259, doi : 10.18393/ejss. 15688.

Malíšek A., 1990: Evaluation of the rainstorm erosion efficiency factor (Zhodnotenie faktora eróznej účinnosti prívalovej zrážky). Geogr. časopis, 42, 4, 410-422 (in Slovak).

Marsh N., Svensmark H., 2000: Cosmic rays, clouds, and climate. Space Sci. Rev., 94, 1-2, 215-230, doi: 10.1023/A:1026723423896.

Melo M., Lapin M., Kapolková H., Pecho J., Kružicová A., 2013: Climate Trends in the Slovak Part of the Carpathians. In: Kozak J., Ostapowicz K., Bytnerowicz A., Wyzga B. (Eds.): The Carpathians: Integrating Nature and Society Towards Sustainability. Environmental Science and Engineering. Springer, Berlin, Heidelberg, doi : 10.1007/978-3-642-12725-0_10.

Nuzhdina M. A., 2002: Connection between ENSO phenomena and solar and geomagnetic activity. Nat. Hazards Earth Syst. Sci., 2, 83-89, doi : 10.5194/nhess-2-83-2002.

Onderka M., Krein A., Wrede S., Martínez-Carreras N., Hoffmann L., 2012: Dynamics of storm-driven suspended sediments in a headwater catchment described by multivariable modeling. J. Soils Sediments, 12, 620-635, doi : 10.1007/s11368-012-0480-6.

Panagos P., Borrelli P., Meusburger K., Yu B., Klik A., Jae Lim K., Yang J. E., Ni J., Miao C., Chattopadhyay N., Sadeghi S. H., Hazbavi Z., Zabihi M., Larionov G. A., Krasnov S. F., Gorobets A. V., Levi Y., Erpul, G., Birkel C., Hoyos N., Naipal V., Oliveira P. T. S., Bonilla C. A., Meddi M., Nel W., Al Dashti H., Boni M., Diodato N., Van Oost K., Nearing M., Ballabio C., 2017: Global rainfall erosivity assessment based on high-temporal resolution rainfall records. Sci. Rep., 7, 4175, doi : $10.1038 / \mathrm{s} 41598-017-04282-8$. 
Prokoph A., Adamowski J., Adamowski K., 2012: Influence of the 11 year solar cycle on annual streamflow maxima in Southern Canada. J. Hydrol, 442-443, 55-62, doi : 10.1016/j.jhydrol.2012.03.038.

Ramachandra Rao A., Hamed K. H., Chen H.-L., 2003: Nonstationarities in Hydrologic and Environmental Time Series. Springer Netherlands.

Routschek A., Schmidt J., Kreienkamp F., 2014: Climate change and soil erosion catena Impact of climate change on soil erosion - A high-resolution projection on catchment scale until 2100 in Saxony/Germany. Catena, 121, 99-109, doi : 10.1016/j. ca tena.2014.04.019.

Š́ri M., Cebecauer T., Hofierka J., Fulajtár E., 2002: Soil erosion assessment of Slovakia at a regional scale using GIS. Ecology (Bratislava), 21, 4, 404-422.

Svensmark H., Friis-Christensen E., 1997: Variation of cosmic ray flux and global cloud coverage-a missing link in solar-climate relationships. J. Atmos. Solar-Terrestrial Phys., 59, 11, 1225-1232, doi: 10.1016/S1364-6826(97)00001-1.

VanderPlas J. T., 2018: Understanding the Lomb-Scargle Periodogram. Astrophys. J. Suppl. Ser., 236, 1, 16, 28 p., doi : 10.3847/1538-4365/aab766.

White W. B., Liu Z., 2008: Non-linear alignment of El Niño to the 11-yr solar cycle. Geophys Res. Lett., 35, 19, L19607, doi: 10.1029/2008GL034831.

Wischmeier W. H., Smith D. D., 1978: Predicting Rainfall Erosion Losses: A guide to Conservation Planning. Science, US Department of Agriculture Handbook, No. 537, Washington DC. 